\title{
UJI AKTIVITAS IMUNOGLOBULIN M (IgM) EKSTRAK ETANOL HERBA RUMPUT MUTIARA (Hedyotis corymbosa) PADA MENCIT (Mus musculus) JANTAN DENGAN METODE HEMAGLUTINASI
}

\author{
Safriani Rahman, Bayu Putra, Rachmat Kosman, Riska Mustika \\ Fakultas Farmasi Universitas Muslim Indonesia \\ Email : Nie_rahman@ymail.com
}

\begin{abstract}
A Research About Activity of Ethanol of Pearl Grass (Hedyotis corymbosa) On The Imunoglobulin M (IgM) by Hemaglutination Method Had Been Conducted of Male Mice. This research purpose to established of activity imunoglobulin M (IgM) from ethanol extract of pearl grass (Hedyotis corymbosa). Mice is animal that used for this research, The mice was divided into 4 treatment groups, where each group consisted of 3 mice. The first group as negative control, and each group was given Sheel Red Blood Cell (SRBC) $2 \%$ as many 0,1 ml intraperitonially, after that negative control group was administrated with air sulingt, and other group was administrated with ethanol extract dose $26 \mathrm{mg}, 78 \mathrm{mg}$, dan $130 \mathrm{mg}$ for five days. The blood from all group was collected by intracardial after five days. The activity of imunoglobulin M (IgM) was measured by hemaglutination method based on titer of the imunoglobulin $M$ (IgM) there was highest dilution of mice blood serum in which aglutination was showed. Research result showed Ethanol extract of Pearl Grass (Hedyotis corymbosa) at $26 \mathrm{mg}, 78 \mathrm{mg}$, and $130 \mathrm{mg}$ dose, can increased imunoglobulin $M$ (IgM) activity.
\end{abstract}

Key words : Imunoglobulin M, Hedyotis corymbosa, Hemaglutination Method

\section{PENDAHULUAN}

Terdapat bermacam-macam mahluk hidup di lingkungan kita. Salah satunya adalah mikroorganisme yang sering kita abaikan keberadaannya. Tidak sedikit dari mikroorganisme ini yang dapat merugikan manusia misalnya virus, jamur, dan parasit yang bertindak sebagai agen infeksi. Banyak dari agen ini dapat menyebabkan kerusakan patologis dan pada akhirnya membunuh hospes jika penyebarannya tidak dihambat. Meskipun demikian, manusia dilengkapi dengan suatu sistem yang berfungsi mempertahankan kekebalan tubuh terhadap mikroorganisme yang dapat merusak. Pada individu normal, sebagian besar infeksi berlangsung dalam jangka waktu terbatas dan menyebabkan sedikit sekali kerusakan permanen, karena sistem imun inilah yang melawan agen infeksi dan mengendalikan atau melenyapkannya 
Uji Aktivitas Imunoglobulin M (IgM) Ekstrak Etanol Herba Rumput Mutiara Metode Hemaglutinasi

sehingga fungsi primer sistem imun adalah melenyapkan agen infeksi dan meminimalkan kerusakan yang terjadi.

Pertahanan tubuh erat kaitanya dengan antibodi. Antibodi merupakan protein imunoglobulin. Imunoglobulin merupakan substansi pertama yang diidentifikasi sebagai molekul dalam serum yang mampu menetralkan sejumlah mikroorganisme penyebab infeksi (Kresno, 1996).

Berbagai upaya telah dilakukan untuk meningkatkan sistem imun manusia agar penyakit-penyakit infeksi yang disebabkan oleh mikroba dapat dicegah bahkan dapat diobati, mengingat banyaknya penyakit infeksi yang tersebar di masyarakat. Pengobatan tradisional merupakan salah satu alternatif yang mulai banyak dilirik oleh masyarakat, mengingat penggunaan obat-obatan sintetik pada umumnya memberikan efek samping. Salah satu tumbuhan yang biasa digunakan oleh masyarakat sebagai obat antiradang adalah rumput mutiara (Hedyotis corymbosa).

Hedyotis corymbosa atau lebih dikenal dengan nama rumput mutiara merupakan kelompok familia Rubiaceae.Hedyotis corymbosa atau rumput mutiara dikenal masyarakat Indonesia sebagai obat penurun panas (dan antiradang. Senyawa yang terkandung di dalamnya antara lain asperulosid, flavonoid, asam ursolic, asam oleanicdan asam triterpene, yang berkhasiat sebagai anti mikroba, anti inflamasi, hepatoprotective, antioxidan dan antikanker. Rumput mutiara (Hedyotis corymbosa)ini telah diteliti efek pemberian ekstraknya terhadap produksi ROI (Reactive Oxygen Intermediate) mencit Balb/cyang diinfeksi Salmonella typhimurium oleh Windy Rezkiana (2006), dimana diperoleh hasil bahwa pemberian ekstrak rumput mutiara (Hedyotis corymbosa) tidak menyebabkan peningkatan yang bermakna terhadap produksi $\mathrm{ROI}$ (Reactive Oxygen Intermediate).

\section{METODE PENELITIAN}

\section{A. Alat dan Bahan}

Alat dan bahan yang akan digunakan disiapkan sesuai dengan kebutuhan penelitian.

\section{B. Prosedur Kerja}

1. Pengambilan Sampel Herba rumput mutiara (Hedyotis corymbosa)

Sampel berupa herba rumput mutiara (Hedyotis corymbosa), sekitar pukul 10.00, diambil seluruh bagian tanaman kecuali bagian akarnya. 
Uji Aktivitas Imunoglobulin M (IgM) Ekstrak Etanol Herba Rumput Mutiara Metode Hemaglutinasi

2. Pengolahan Sampel Herba rumput mutiara (Hedyotis corymbosa)

Sampel herba rumput mutiara (Hedyotis corymbosa) yang telah dikumpulkan, dipotong-potong kecil, dikeringkan dengan cara diangin-anginkan pada tempat yang tidak terkena sinar matahari langsung.

3. Pembuatan Ekstrak Etanol Herba Rumput Mutiara (Hedyotis corymbosa)

Herba rumput mutiara (Hedyotis corymbosa) yang telah dikeringkan dimasukkan ke dalam bejana maserasi, ditambahkan pelarut etanol hingga sampel terendam. Dibiarkan selama 5 hari dengan sesering mungkin diaduk. Setelah 5 hari, disaring kemudian diperas dan ditambah cairan penyari lagi, penyaringan dilakukan tiga kali. Sari yang diperoleh diuapkan dengan rotavapor.

\section{Sel Darah Merah Domba} (SDMD) $2 \%$

Sel darah merah domba ditampung dalam wadah bersih dan kering yang berisi serbuk EDTA sebagai antikoagulan.
Untuk $1 \mathrm{ml}$ darah domba, diperlukan $1 \mathrm{mg}$ EDTA. Pisahkan sel darah merah domba dengan plasmanya dengan pemusingan pada sentrifuge $\quad 1500 \quad$ rpm. Selanjutnya cuci sel darah merah dengan menambahkan larutan PBS (Phosfat Buffered Saline) dalam jumlah besar dan tabung berisi suspensi tersebut dibolak-balik beberapa kali dan disentrifuge kembali. Lakukan pencucian paling sedikit 3 kali. Setelah selesai, PBS dibuang dan diperoleh SDMD $100 \%$. Kemudian pada SDMD $100 \%$ tadi ditambahkan PBS dengan volume sama hingga diperoleh SDMD 50 \%. Siapkan antigen yang akan digunakan dengan mengencerkan 0,4 $\mathrm{ml}$ suspensi SDMD $50 \%$ dengan $9,6 \mathrm{ml}$ PBS sehingga diperoleh $10 \mathrm{ml}$ suspensi antigen (SDMD $2 \%$ )

5. Pembuatan Larutan PBS (Phosfat Buffered Saline)

Posfat Buffered Saline (PBS) disiapkan dengan terlebih dahulu membuat larutan $A$ yaitu larutan $\mathrm{NaH}_{2} \mathrm{PO}_{4}$ 1,38 $\mathrm{g} / \mathrm{L}$ dan $\mathrm{NaCl} 8,3 \mathrm{~g} / \mathrm{L}$ dan larutan $B$ yaitu $\mathrm{Na}_{2} \mathrm{HPO}_{4} 1,42$ $\mathrm{g} / \mathrm{L} \quad$ dan $\mathrm{NaCl} \quad 8,5 \quad \mathrm{~g} / \mathrm{L}$ 
Uji Aktivitas Imunoglobulin M (IgM) Ekstrak Etanol Herba Rumput Mutiara Metode Hemaglutinasi

selanjutnya $280 \mathrm{ml}$ larutan A ditambahkan pada $720 \mathrm{ml}$ larutan B.

\section{Perlakuan Hewan Uji}

Mencit dimunisasi
dengan suspensi sel darah
merah domba $2 \%$ dengan
volume 0,1 ml/ekor secara
intraperitonial kemudian
dilakukan perlakuan dimana
kelompok kontrol diberi air
suling dengan volume 1 ml
secara oral, kelompok I diberi
ekstrak etanol herba rumput
mutiara (Hedyotis corymbosa)
dengan dosis 26 mg, kelompok
II dengan dosis 78 mg, dan
kelompok IIl dengan dosis 130
mgmasing-masing sebanyak 1
ml secara oral. Perlakuan
dilakukan selama lima hari.
Selanjutnya pada hari kelima
setelah imunisasi, darah mencit
diambil secara intrakardial
sebanyak 1 ml dengan
menggunakan spoit kemudan
ditampung dalam vial.

\section{Pengujian aktivitas IgM}

Darah yang telah diambil selanjutnya dibiarkan menggumpal pada suhu kamar selama 1-2 jam. kemudian disentrifuge dengan kecepatan 3000 rpm selama 10 menit dan diambil serumnya . Serum selanjutnya diencerkan secara "double dilution" $1 / 4,1 / 8,1 / 16$, $1 / 32,1 / 64,1 / 128,1 / 256,1 / 512$ dengan PBS sebanyak $50 \mu \mathrm{L}$ untuk setiap sumur pada piring mikrotitrasi (wheel plate 96) selanjutnya pada sumur ditambahkan $50 \mu \mathrm{L}$ suspensi sel darah merah domba $2 \%$ lalu diaduk rata (digoyanggoyangkan) selama 5 menit. Selanjutnya diinkubasi pada $37^{\circ} \mathrm{C}$ selama 60 menit dan didiamkan semalaman pada suhu kamar. Dilakukan pengamatan tertinggi dan serum darah mencit yang masih dapat mengaglutinasi sel darah merah domba 
Uji Aktivitas Imunoglobulin M (IgM) Ekstrak Etanol Herba Rumput Mutiara Metode Hemaglutinasi

HASIL PENELITIAN

Tabel 1. Titer Imunoglobulin (IgM)

\begin{tabular}{ccccc}
\hline \multirow{2}{*}{ Perlakuan } & \multicolumn{4}{c}{ Titer imunoglobulin M (IgM) } \\
\cline { 2 - 5 } & Kontrol & $\begin{array}{c}\text { Kelompok I } \\
(\mathbf{2 6} \mathbf{~ m g )}\end{array}$ & $\begin{array}{c}\text { Kelompok II } \\
\mathbf{( 7 8} \mathbf{~ m g )}\end{array}$ & $\begin{array}{c}\text { Kelompok III } \\
\text { (130 } \mathbf{~ m g )}\end{array}$ \\
\hline Replikasi 1 & $1 / 8$ & $1 / 64$ & $1 / 64$ & $1 / 16$ \\
Replikasi 2 & $1 / 8$ & $1 / 64$ & $1 / 32$ & $1 / 16$ \\
Replikasi 3 & $1 / 8$ & $1 / 64$ & $1 / 32$ & $1 / 16$ \\
\hline
\end{tabular}

PEMBAHASAN

Penentuan

aktivitas

imunoglobulin M (lgM) ekstrak etanol herba rumput mutiara (Hedyotis corymbosa) bertujuan untuk menguji aktivitas imunoglobulin $\mathrm{M}$ (IgM) ekstrak etanol herba rumput mutiara (Hedyotis corymbosa) dengan menggunakan metode hemaglutinasi. Pada metode hemaglutinasi sel darah merah diaglutinasi oleh antibodi yang menyerang antigen yang telah digabungkan secara kimiawi pada permukaan sel darah merah. Jadi sel darah merah merupakan indikator nyata dari interaksi antigen dan antibodi. Pengujian aktivitas imunoglobulin M (IgM) menggunakan metode hemaglutinasi berdasarkan titer imunoglobulin $M \quad(\lg M)$ yaitu pengenceran tertinggi serum darah mencit yang masih menunjukkan aglutinasi. Kelebihan dari metode hemaglutinasi adalah proses pengamatan yang dapat dilakukan dengan cepat, karena hanya melihat reaksi aglutinasi positif dari sampel.
Selain itu, bahan dan alat yang digunakan mudah didapatkan.

Aglutinasi terjadi bila antigen yang berbentuk partikel direaksikan dengan antibodi spesifik. Antibodi tersebut disebut spesifik jika hanya bereaksi dengan antigen yang merangsang produksinya. Gumpalan yang terbentuk antara antigen dan antiserum spesifik akan bersatu dan akhirnya mengendap sebagai gumpalan-gumpalan besar dan mudah terlihat. Hal ini terjadi karena pada umumnya antibodi memiliki lebih dari satu reseptor pengikat antigen sehingga antibodi bereaksi dengan molekul antigen lain yang mungkin berikatan dengan salah satu molekul antibodi dan terbentuklah gumpalan. Reaksi aglutinasi dibantu oleh suhu tinggi $\left(37^{0}\right)$, oleh gerakan yang menambah kontak antigen dengan antibodi (misalnya mengocok, mengaduk, atau memusing) dan dengan adanya larutan yang mengandung garam 
Uji Aktivitas Imunoglobulin M (IgM) Ekstrak Etanol Herba Rumput Mutiara Metode Hemaglutinasi

menyebabkan berkumpulnya

gumpalan.

Antigen yang digunakan dalam penelitian ini adalah sel darah merah domba (SDMD) karena merupakan antigen yang terbaik untuk pengujian produksi antibodi pada hewan percobaan mencit, keutamaan SDMD dari antigen lain adalah SDMD mudah diperoleh dalam suspensi yang uniform dan dapat diukur, cukup stabil, dan lisisnya dapat dilihat dengan mudah.

Aglutinasi terjadi bila antigen yang berbentuk partikel direaksikan dengan antibodi spesifik. Antibodi tersebut disebut spesifik jika hanya bereaksi dengan antigen yang merangsang produksinya. Gumpalan yang terbentuk antara antigen dan antiserum spesifik akan bersatu dan akhirnya mengendap sebagai gumpalan-gumpalan besar dan mudah terlihat. Hal ini terjadi karena pada umumnya antibodi memiliki lebih dari satu reseptor pengikat antigen sehingga antibodi bereaksi dengan molekul antigen lain yang mungkin berikatan dengan salah satu molekul antibodi dan terbentuklah gumpalan. Reaksi aglutinasi dibantu oleh suhu tinggi $\left(37^{\circ}\right)$, oleh gerakan yang menambah kontak antigen dengan antibodi (misalnya mengocok,

mengaduk,atau memusing) dan dengan adanya larutan yang mengandung garam (PBS) menyebabkan berkumpulnya gumpalan.

Dari hasil pengamatan titer aglutinasi, menunjukkan peningkatan aktivitas imunoglobulin M (IgM). Hal ini dapat dilihat pada kelompok perlakuan pemberian ekstrak etanol herba rumput mutiara (Hedyotis corymbosa) dengan masing-masing dosis. $26 \mathrm{mg}$, $78 \mathrm{mg}$ dan $130 \mathrm{mg}$, titer imunoglobulin masing-masing sebesar 1/64, 1/32, dan 1/16 sedangkan kelompok kontrol rata-rata titer imunoglobulinnya hanya $1 / 8$.

Titer imunoglobulin M (lgM) dari serum darah mencit yang diberikan ekstrak etanol herba rumput mutiara (hedyotis corymbosa) mengalami peningkatan tertinggi pada dosis 26 mg dimana titer naik tiga tingkat pengenceran dibandingkan kontrol tetapi seiring dengan terjadinya peningkatan dosis ekstrak, titer mengalami penurunan tingkat pengenceran. Hal ini disebabkan karena reaksi imun sangat ditentukan oleh kesetimbangan jumlah antigen dan antibodi. Apabila jumlah antigen atau antibodi tidak seimbang (salah satunya berlebihan), maka reaksi imun akan terganggu. 
Uji Aktivitas Imunoglobulin M (IgM) Ekstrak Etanol Herba Rumput Mutiara Metode Hemaglutinasi

\section{KESIMPULAN}

Kesimpulan yang dapat ditarik dari penelitian ini bahwa pemberian ekstrak etanol herba rumput mutiara (Hedyotis corymbosa) dengan dosis $26 \mathrm{mg}, 78 \mathrm{mg}$ dan 130 mg dapat meningkatkan aktivitas immunoglobulin $\mathrm{M}$ (IgM) terhadap mencit (Mus musculus) jantan

\section{DAFTAR PUSTAKA}

Baratawidjaja, G. K. 2004. Imunologi Dasar, Edisi VI. Penerbit Fakultas Kedokteran Universtas Indonesia: Jakarta.

Dalimartha, Setiawan. 2008. Atlas Tumbuhan Obat Indonesia Jilid 5. Pustaka Bunda: Jakarta.

Darmono. 2006. Farmakologi dan Toksikologi Sistem Kekebalan: Pengaruh Penyebab dan Akibat pada Kesehatan Tubuh,Penerbit UI-Press: Jakarta.

Direktorat Jendral Pengawasan Obat dan Makanan. 1986. Cara Pembuatan Simplisia, Departemen Kesehatan Republik Indonesia: Jakarta.

Gard, Paul. 2002.Human Pharmacology. Taylor and Francis Group: Brigthon, UK.
Jasin, M. 1992.Zoologi Vertebrata untuk Perguruan Tinggi. PT.Antariksa: Surabaya.

Kresno B. S. 1996. Imunologi: Diagnosis dan Prosedur Laboratorium Edisi III. Penerbit Fakultas Kedokteran Universitas Indonesia: Jakarta.

Malole M.B.M. dan Pramono C.S.U. 1989.Penggunaan hewanhewan Percobaan Laboratorium, Penelaan: Masduki partad, Departemen Pendidikan dan Kebudayaan Direktorat Jendral Pendidikan Tinggi Pusat Antar Universitas Bioteknologi, IPB: Bogor.

Radji, Maksum. 2010. Imunologi dan Virologi. PT. ISFI Penerbitan: Jakarta

Rezkiana, Windy. 2006.Pengaruh Pemberian Ekstrak Rumput Mutiara (Hedyotis corymbosa) Terhadap ProduksiROI Mencit Balb/c yang diinfeksi Salmonella typhimurium. Http://undip.ac.id. diakses 28 November 2011.

Rose, N. 1973. Principles immunology, Eight Edition. Black well Scientific Publication: London.

Wahab, S.A., dan Julia M. 2002. Sistem Imun, Imunisasi, dan Penyakit Imun. Widya Medika: Jakarta. 